Forest Industries Association, his services were loaned by the Association on a part-time basis to the Pulp and Paper Industry of Canada, as SecretaryManager of the Pulpwood Committee of the pulp and paper industry. That Committee functioned as a liaison body between the industry and various Government Departments, such as Labour, Munitions and Supply. Coincident with his appointment in this latter office, he was also appointed Secretary of the Industrial Advisory Committee which acted in an advisory capacity to the Timber Controller.

In October, 1947, he resigned from the Quebec Forest Industries Association to take over managership of the re-organized Woodlands Section of the Canadian Pulp and Paper Association when Mr. A. Koroleff, the former Manager of the Section, was appointed Director of Woodlands Research of the Pulp and Paper Research Institute of Canada.

W. A. E. Pepler is a member of the Quebec Society of Forest Engineers, the Canadian Forestry Association, and the Quebec Forestry Association, as well as the Canadian Institute of Forestry. He is the present Chairman of the Quebec Section and has been a member of many committees dealing with forestry matters, including those dealing with ethics and forest policies.

He resides in Westmount, Quebec, married the former Joan Chadwick of Toronto, and has one son, Stanley, and one daughter, Carolyn.

\title{
SUPPLEMENTARY REPORT OF THE STANDING COMMITTEE ON SURVEYS
}

In view of recent suggestions the following revisions in the 1950 report of the Standing Committee on Surveys are recommended.

1. Under Non-productive and Non-forested the designations Hay meadow and Grassland would be better called Grassland, moist and Grassland, welldrained.

2. The paragraph immediately following the list of Non-productive and Nonforested symbols would then be replaced by the following:

"Grassland, moist, refers to low, level, grass-covered land of finely formed soil, firm enough for easy mowing. Grassland, well- drained, includes rolling land suitable for grazing."

Also the following two paragraphs should be inserted after the above:

"For clarity and time-saving, scatter the symbols or fringe the area with them."

"The symbols, both for Depleted and for Non-productive and Nonforested may be used on the same area. If, however, reproduction is unknown immediately after a fire, cut, or other depletion omit symbols temporarily, but show in inventory records as young growth."

3. Under Forest Classification-Height, for Detailed Surveys, the alternative - "or 6 to 15 feet with a special symbol for 5 feet and under" might be inserted under the first category of "Up to 15 feet".

4. Under Crown Closure (or other density criterion) for Detailed Surveys, the alternative- "or $6 \%$ to $15 \%$ with a special symbol for $5 \%$ and under" might be inserted after the first category of "Up to $15 \%$ ".

W. H. Hilborn, Secretary

H. E. Seely, Chairman 